\title{
KEDUDUKAN NOTARIS SEBAGAI DIREKTUR DALAM PERSFEKTIF PERATURAN PERUNDANG-UNDANGAN YANG BERLAKU
}

\author{
Ady Prasetya Radam
}

Biro Konsultan Hukum Provinsi Kalimantan Selatan

Jn. Pekapuran Laut, Banjarmasin Tengah, Kota Banjarmasin, Kalimantan Selatan, Indonesia 70234 Telp: +62 812-1714-8548+E-mail :radam.adyprasetya@yahoo.com

Diterima: 16/01/2017; Revisi:27/09/2017; Disetujui:30/09/2017

\begin{abstract}
This research aims at studying and analyzing the ratio legis of the provison on the double position of the Notary Publics as stipulated in Artecle 17 of Act Number 2 of 2012 concerning Notary Public's Office and analyzing the provision of Article 93 paragraph (1) of Act Number 40 of 2007 concerning Limited Company in relation with the position of the Notary Public as Director. This is normative legal research by conducting library study mainly secondary legal resources. This research applies statute apporoach by studying all acts and regulations related with the legal issue being dealt with. The nature of this research perspective analytical, i.e to explain precisely the caharacteristics of an individual, condition/phenomena of the groups in order to determine the spead of a phenomenon and to determine the existence of relation between one phenomenon to the order in the society. The results of this research are firstly, the ratio legis of the provision on the double position of the Notary Public as stipulated in Article 17 of Act Number 2 of 2014 concerning Notary Public's Office is to avoid double position which may lead to conflict of interest. If a the Notary Public has doble position as director, it is clear that there are differences the Notary Public of authorities, and this may cause abuse of power. Secondly, a Notary Public holds a position as a director as stipulated in Article 93 paragraph (1) of Act Number 40 of 2007 concerning Limited Company is not possible. Articles 17 of Act Number 2 of 2014 concerning Notary Public's Office prohibits double position. Limited Company Act does not explicity mentions about double position in a Limited Company, but it is clearly done because the tasks and authorities of a Notary Public and a Director are very distict and double position may bring about conflict of authorities.
\end{abstract}

Keywords : Notary; Director; Legislation

Abstrak: Tujuan yang ingin dicapai dari penelitian ini adalah menganalisis ratio 
logis dari ketentuan rangkap jabatan notaris sebagaimana tercantum dalam Pasal 17 Undang-Undang Nomor 2 Tahun 2014 Tentang Jabatan Notaris dan untuk menganalisis ketentuan Pasal 93 ayat (1) Undang-Undang Nomor 40 Tahun 2007 Tentang Perseroan Terbatas terkait dengan persoalan notaris berkedudukan sebagai direktur. Peneliti menggunakan jenis penelitian hukum normatif yaitu pendekatan penelitian yang dilakukan adalah penelitian kepustakaan,. Penelitian ini juga dilakukan dengan pendekatan perundang-undangan yang dilakukan dengan menelaah semua undang-undang dan relugasi yang bersangkut paut dengan isu hukum yang sedang ditangani. Sedangkan sifat penelitian ini bersifat Presfektif analitis yaitu penelitian yang memiliki tujuan untuk menjelskan secara tepat dari sifat-sifat suatu individu, kondisi/gejala keleompok tertentu/untuk menentukan penyebaran dari suatu gejala untuk menentukan ada dan tidaknya hubungan antara satu gejala dengan gejala lain di dalam masyarakat. Hasil Penelitian :Pertama Ratio legis yang melatar belakangi dari ketentuan rangkap jabatan notaris sebagaimana tercantum dalam Pasal 17 Undang-Undang Nomor 2 Tahun 2014 Tentang Jabatan Notaris adalah jangan sampai terjadi rangkap jabatan, karena akan menimbulkan benturan kepentingan. Dan dalam hal Notaris merangkap jabatan sebagai direktur maka sudah bisa jelas dilihat adanya perbedaan kewenangan, dan perbedaan kewenangan ini yang ditakutkan terjadinya penyalahgunaaan wewenang. Seorang notaris berkedudukan sebagai direktur sebagaimana ketentuan Pasal 93 ayat (1) Undang-Undang Nomor 40 Tahun 2007 Tentang Perseroan Terbatas adalah bahwa yang diangkat untuk menjadi seorang direktur adalah mereka yang cakap melakukan perbuatan hukum dan ada pengecualiannya terhadap pengangkatan seseorang sebagai direktur. Tidak ada hal yang mengatur masalah rangkap jabatan seorang direktur.

Keywords: Notaris; Direktur; Perundang-Undangan

\section{PENDAHULUAN}

Undang-Undang Nomor 2 Tahun 2014 Tentang Jabatan Notaris, pada Pasal 1 angka 1 menyebutkan bahwa Notaris adalah Pejabat umum yang yang berwenang untuk membuat akta otentik dan kewenangan lainnya sebagaimana dimaksud dalam Undang-Undang ini. Pejabat Umum adalah organ negara yang dilengkapi dengan kekuasaan umum, berwenang menjalankan sebagian dari kekuasaan negara untuk membuat alat bukti tertulis dan otentik dalam bidang hukum perdata.Dan notaris selaku pejabat umum merupakan organ negara yang diperlengkapi dengan kekuasaan umum, berwenang menjalankan sebagian kekuasaan negara untuk membuat akta tertulis dan otentik dalam bidang Hukum perdata.

Ketentuan pasal 17 tersebut di atas mengandung larangan terhadap notaris dalam hal menjalankan jabatan di luar wilayah jabatannya, meninggalkan wilayah jabatannya lebih dari 7 (tujuh) hari kerja berturut turut, merangkap sebagai pegawai negeri, merangkap jabatan sebagai advokad, merangkap jabatan sebagai pejabat Negara, merangkap jabatan sebagai pimpinan atau pegawai Badan 
Usaha Milik Negara, Badan Usaha Milik Daerah, Badan Usaha Milik Swasta, merangkap jabatan sebagai Pejabat Pembuat Akta Tanah di luar wilayah jabatan notaris, menjadi notaris pengganti dan melakukan pekerjaan lain yang bertentangan dengan norma agama, kesusilaan atau keputusan yang dapat mempengaruhi kehormatan dan martabat jabatan notaris

Berdasarkan ketentuan pasal 17 dan pasal 52 UUJN tersebut di atas dapat disimpulkan bahwa terdapat ketentuan yang jelas bagi seorang notaris bahwa seorang notaris pada prinsipnya tidak diperbolehkan bahkan di larang untuk memiliki jabatan rangkap

Terkait rangkap jabatan dalam sebuah perusahaan atau perseroan Undang-Undang Nomor 40 Tahun 2007 Tentang Perseroan Terbatas tidak mengatur mengenai rangkap jabatan, sedangkan dalam Undang-Undang Nomor 2 Tahun 2014 tentang Peraturan Jabatan Notaris, pada Pasal 17 melarang notaris rangkap jabatan. Sedangkan dalam kenyataannya ada Notaris sebagai pimpinan Perseroan Terbatas dan juga sebagai pegawai Perseroan Terbatas.

\section{METODE}

penelitian ini ,menggunakan jenis penelitian hukum normatif. Penelitian hukum normatif adalah penelitian hukum yang meletakkan hukum sebagai sebuah bangunan sistem norma. ${ }^{1}$ Peter Mahmud Marzuki menjelaskan penelitian hukum normastif adalah :2 "Suatu proses untuk menemukan suatu aturan hukum, prinsip-prinsip hukum, maupun doktrin-doktrin hukum untuk menjawab permasalahan hukum yang dihadapi. Penelitian hu- kum normatif dilakukan untuk menghasilkan argumentasi, teori atau konsep baru sebagai preskripsi dalam menyelesaikan masalah yang sedang dihadapi”.

Penulis memilih tipe "Doctrinal Research" yaitu secara sistematisasi mengkoreksi dan memperjelas suatu aturan hukum yang berlaku pada bidang hukum tertentu dengan cara melakukan analisis terhadap teks yang bersifat autoritatif yang meliputi bahan hukum primer dan sekunder. ${ }^{3}$ Dalam hal ini penulis menganalisis tentang ketentuan rahasia bank pada Pasal 40 Undang-Undang Nomor 10 Tahun 1998 Tentang Perbankan yang menyatakan bahwa nasabah penyimpan dan simpanannya lah yang wajib untuk dirahasiakan. Hal ini dipersempit dengan tidak lagi memuat nasabah debitur dalam hal ketentuan rahasia bank.

Pendekatan yang digunakan sesuai dengan rumusan masalah dalam penelitian ini adalah pendekatan perundang-undangan (statute apporach) dan pendekatan konseptual. Pendekatan undang-undang adalah pendekatan yang dilakukan dengan menelaah semua undang-undang dan regulasi yang bersangkut paut dengan isu hukum yang diketengahkan. ${ }^{4}$ Dan penulis melakukan pendekatan terhadap Undang-Undang Perbankan dan Peraturan Bank Indonesia. Sedangkan pendekatan konseptual dilakukan manakala peneliti tidak beranjak dari aturan hukum yang ada. Dalam menggunakan pendekatan konseptual peneliti perlu merujuk prinsip-prinsip hukum yang dapat ditemukan dalam perundang-undangan para sarjana ataupun doktrin-doktrin

3 Dyah Ochtorina Susanti dan A'an Efendi. 2014. Penelitian Hukum (Legal Research). Jakarta: Sinar Grafika, hlm. 15.

4 Peter Mahmud Marzuki. Op. Cit, hlm. 93 
hukum. $^{5}$

ANALISIS DAN PEMBAHASAN

Ratio Legis Ketentuan Rangkap Jabatan Sebagaimana Tercantum dalam UndangUndang Nomor 2 Tahun 2014 tentang Jabatan Notaris

Dalam penjelasan Pasal 17 maksud dari larangan adalah untuk menjamin kepentingan masyarakat yang memerlukan jasa Notaris. Dan larangan ini juga untuk memberi kepastian hukum kepada masyarakat dan sekaligus mencegah terjadinya persaingan tidak sehat antar Notaris dalam menjalankan jabatannya.

Peranan hukum dalam mengatur kehidupan masyarakat sudah dikenal sejak masyarakat sudah dikenal sejak masyarakat mengenal hukum itu sendiri, sebab hukum itu dibuat untuk mengatur kehidupan manusia sebagai mahluk sosial, hubungan antar masyarakat dan hukum. Melihat perkembangan hukum dalam masyarakat, maka akan ditemukan bahwa peranan hukum dalam mengatur kehidupan masyarakat mengalami perubahan dan perbedaan dari suatu kurun waktu tertentu ke waktu yang lain.

Dalam masyarakat yang sederhana, hukum berfungsi untuk menciptakan dan memelihara keamanan serta ketertiban. Fungsi ini berkembang sesuai dengan perkembangan masyarakat itu sendiri yang meliputi berbagai macam aspek kehidupan masyarakat yang bersifat dinamis yang memerlukan kepastian, ketertiban, dan perlindungan hukum yang berintikan kebenaran dan keadilan. Kehidupan masyarakat yang memerlukan sector pelayanan jasa publik yang saat ini semakin berkembang seiring meningkatnya kebutuhan masyarakat antarapelayanan jasa.

Hal ini juga berdampak pada peningka-

5 Ibid, tan di bidang jasa. Peran Notaris dalam sektor pelayanan jasa adalah sebagai pejabat yang diberi wewenang oleh Negara untuk melayani masyarakat dalam bidang perdata khususnya pembuatan akta otentik.

Landasan Filosofis dibentuknya UUJN adalah terwujudnya jaminan kepastian hukum, ketertiban dan perlindungan hukum yang berintikan kebenaran dan keadilan melalui akta yang dibuatnya. Notaris harus memberikan kepastian hukum kepada masyarakat pengguna jasa Notaris. Dan produk hukum yang dikeluarkan oleh Notaris adalah berupa akta-akta yang memiliki sifat otentik dan memiliki kekuatan pembuktian yang sempurna.

Dengan maksud itupulalah maka Notaris dilarang merangkap jabatan seperti di atas. Karena besar sekali tanggung jawab yang diberikan kepada Notaris dalam hal pembuatan akta-akta otentik serta kewenangan lain yang dimaksud dalam Pasal 15 ayat (1) UUJN

Dalam Undang-Undang Jabatan Notaris , dengan jelas disebutkan mengenai rangkap jabatan. Seorang Notaris pada dasarnya dilarang menjalankan jabatan di luar wilayah jabatannya, meninggalkan wilayah jabatannya lebih dari 7 (tujuh) hari kerja berturut-turut tanpa alasan yang sah, merangkap jabatan sebagai pegawai negeri, merangkap jabatan sebagai pejabat negara, merangkap jabatan sebagai advokad, merangkap jabatan sebagai pemimpin atau pegawai badan usaha milik negara, badan usaha milik daerah atau badan usaha swasta, merangkap jabatan sebagai Pejabat Pembuat Akta Tanah atau melakukan pekerjaab lain yang bertentangan dengan norma agama, kesusilaan atau kepatutan yang dapat mempengaruhi kehormatan dan martabat jabatan Notaris.

Larangan ini sangat mendasar karena Notaris adalah sebagai Pejabat Umum yang 
memiliki tugas dan wewenang dalam jabatannya, dan ketika Notaris merangkap jabatan, maka tentu saja akan terjadi timpang tindih antara pekerjaan yang satu dengan pekerjaan yang lain. Sedangkan tugas utama seorang Notaris adalah seperti yang telah disebutkan yaitu membuat akta otentik.

Tugas seorang Notaris sangatlah berat, mengingat Notaris mempunyai kedudukan dan peran yang sangat penting dalam kehidupan berbangsa dan bernegara, karena mempunyai kewenangan yang telah ditentukan dalam peraturan perundang-undangan. Dan dalam menjalankan tugasnya tersebut Notaris harus menjalankan semua tugas, kewajiban, kewenangan yang harus dilaksanakannya serta juga larangan-larangan yang harus dihindarinya berkaitan dengan jabatan yang diembannya. Ketika jabatan itu harus dirangkap dengan jabatan lain tentu terjadi kurang optimal dalam hal melaksanakan pekerjaan. Selain itu juga sangat jelas bahwa seorang Notaris yang merangkap jabatan haruslah dikenakan saksi karena telah melanggar apa yang telah diamanatkan dalam undang-undang, terutama Pasal 17 ayat (1) Undang-Undang Jabatan Notaris yang memuat tentang apa saja yang dilarang bagi Notaris.

Majelis Pengawas adalah suatu badan yang mempunyai kewenangan dan kewajiban untuk melaksanakan pembinaan dan pengawasan terhadap Notaris yang meliputi perilaku dan pelaksanaan jabatan Notaris. Sesuai dengan ketentuan Undang-undang Jabatan Notaris Majelis Pengawas Notaris mengawasi bukan saja perilaku Notaris, tetapi juga pelaksanaan jabatan Notaris.

Dalam pembahasan permasalahan yang dibahas mengenai larangan rangkap jabatan Notaris, di mana larangan tersebut merupakan aturan yang memerintahkan kepada
Notaris untuk tidak melakukan sesuatu yang bertentangan dengan peraturan perundangundangan yang berlaku. Larangan bagi Notaris tercantum dalam Pasal 17 ayat (1) Undang-Undang Nomor 2 Tahun 2014 tentang Perubahan Atas Undang-Undang Nomor 30 Tahun 2004 tentang Jabatan Notaris.

Ketika Notaris melanggar larangan tersebut, dengan melakukan rangkap jabatan maka wewenang Majelis Pengawas terhadap Notaris yang rangkap jabatan adalah Majelis Pengawas Notaris tidak bisa bertindak tanpa ada laporan dari masyarakat. Pasal 70 Undang-Undang Jabatan Notaris huruh g hanya memberi wewenang kepada Majelis Pengawas Daerah untuk menerima laporan dari masyarakat mengenai adanya dugaan pelanggaran kode etik. Meskipun demikian anggota Majelis Pengawas Notaris Daerah wajib menindaklanjuti laporan masyarakat tadi dengan cara memeriksa Notaris yang dilaporkan, lalu menyampaikan hasil pemeriksaan itu ke Majelis Pengawas Notaris paling lambat 30 (tiga puluh) hari.

Berati di sini selain ada laporan dari masyarakat terhadap rangkap jabatan yang dilakukan oleh seorang Notaris, Majelis Pengawas harus juga aktif dalam melakukan pengawasan terhadap perilaku Notaris dan pelaksanaan jabatan Notaris. Melalui Majelis Pengawas Daerah, Majelis Pengawas Wilayah, dan Majelis Pengawas Pusat, bisa secara optimal dalam melakukan pengawasan terhadap Notaris, tanpa harus menunggu laporan dari masyarakat.

Ketika Majelis Pengawas telah menemukan pelanggaran yang dilakukan Notaris yang menjalankan rangkap jabatan dengan jabatan yang lain, maka Majelis Pengawas dapat dikenakan saksi, berupa :

1. Peringatan tertulis; 
2. Pemberhentian sementara;

3. Pemberhentian dengan hormat; atau Pemberhentian dengan tidak hormat.

Penafsiran Pasal 93 Ayat (1) Undang-Undang Nomor 40 Tahun 2007 tentang Perseroan Terbatas Terkait Kedudukan Notaris sebagai Direktur

Mengenai posisi rangkap jabatan di dalam sebuah perseroan terbatas yang itu legal mengingat Undang-Undang Perseroan Terbatas menentukan batas minimum jumlah pendiri hanyalah dua orang meskipun pendiri yang hanya dua orang mungkin menunjuk pihak ketiga untuk duduk sebagai direksi atau komisaris tapi hal ini jarang sekali dilakukan. Karena hanya untuk memenuhi syarat perseroan terbatas tidak jarang seorang pendiri yang meminjam nama orang lain untuk duduk sebagai pendiri yang meminjam nama orang lain untuk duduk sebagai pendiri dan hanya mengambil saham $1 \%$. Sehingga jika menentukan siapa yang duduk sebagai pendiri kadang sering asal-asalan,

Di dalam Undang-Undang Perseroan Terbatas disebutkan bahwa organ perseroan terbatas terdiri atas RUPS, Komisaris dan Direksi. Pada dasarnya ketiga organ tersebut melengkapi kebutuhan sebuah perusahaan agar dapat beroperasi secara maksimal, karena masing-masing menjalankan fungsi sendirisendir yang mandiri yakni direksi mengurus fungsi pengurusan, komisaris menjalankan fungsi pengawasan dan RUPS melaksanakan fungsi di luar fungsi mengurusi dan mengawasi. Kewenangan ketiga organ tersebut masing-masing diatur di dalam Undang-Undang Perseroan Terbatas. ${ }^{6}$

Undang-Undang Jabatan Notaris tidak

6 Wordpress.com/2012/11/8/legalitas-rangkapjabatan-organ-PT, diakses 2 Januari 2016. mengatur susunan rangkap jabatan di dalam sebuah perseroan terbatas, padahal di dalam Pasal 7 ditentukan batas minimal jumlah pendiri 2 (dua) orang. Hal ini menunjukan ketidakefektifan ketentuan organ persroan dan kewenangan organ persreroan yang di dalam Undang-Undang Perseroan Terbatas. Mengenai rangkap jabatan di sini ditakutkan akan mengalami benturan dengan kepentingan baik langsung maupun tidak langsung atas tindakan pengurusan yang mengakibatkan kerugian bagi Perseroan itu sendiri.

Misalnya rangkap jabatan antara Direksi dan Komisaris dalam suatu Perseroan Terbatas. Di atas sudah dijelaskan apa yang menjadi tugas bagi seorang Direksi. Sedangkan tugas bagi seorang Komisaris adalah melakukan pengawasan atau kebijkaan pengurusan, jalannya pengurusan pada umumnya, baik mengenai Perseroan maupun usaha Perseroan dan member nasehat kepada Direksi (Pasal 108 ayat (1) Undang-Undang Perseroan Terbatas).

Bila kita lihat dua ketentuan mengenai Direksi dan Dewan Komisaris tersebut, sudah dapat diketahui bahwa tugas utama Direksi adalah melakukan pengurusan Perseroan Terbatas sedangkan tugas utama Dewan Komisaris adalah melakukan pengawasan atas pengurusan Perseroan Terbatas. Jika di dalam suatu Perseroan Terbatas Direksi merangkap sebagai Dewan Komisaris terlebih lagi bila dipegang oleh satu orang, maka akan berakibat munculnya benturan kepentingan. Benturan kepentingan ini karena jalannya pengurusan Perseroan Terbatas dikhawatirkan tidak terkendali sebab kewenangan untuk melakukan pengawasan dan pengurusan dipegang oleh orang yang sama.

Apabila terjadi kerugian atau kepailitan akibat benturan kepentingan dalam penguru- 
san Perseroan Terbatas, Direksi yang merangkap Dewan Komisaris tidak bisa mengelak dari tanggung jawab penuh secara pribadi sebab berdasarkan Pasal 95 ayat (5) huruf c Jo. Pasal 104 ayat (4) huruf c Undang-Undang Perseroan Terbatas, Direksi yang dapat membuktikan tidak mempunyai benturan kepentingan baik langsung maupun tidak langsung atas tindakan pengurusan yang mengakibatkan kerugian, tidak dapat dipertanggungjawabkan atas kerugian atau kepailitan Perseroan Terbatas.

Mengenai benturan kepentingan ini, M. Yahya Harahap menyatakan dalam melaksanakan pengurusan Perseroan Terbatas, bahwa Anggota Direksi wajib menghindari terjadinya "benturan kepentingan" (conflict of interest) dalam pelaksanaan pengurusan Perseroan. ${ }^{7}$ Setiap tindakan pengurusan yang mengandung benturan kepentingan, dikatagorokan sebagai tindakan itikad buruk (bad faith). Sebab tindakan yang demikian melanggar kewajiban kepercayaan (breach of his fiduciary duty) dan kewajiban mentaati peraturan perundang-undangan.

Masalah rangkap Notaris sebagai pegawai negeri sipil di sini dilarang tentu saja berkaitan dengan kewenangannya masingmasing. Dan kewenangan masing-masing ini jangan sampai saling berbenturan yang nantinya sangat merugikan pada masayarakat. Kewenangan Notaris menurut Pasal 15 UUJN adalah membuat akta otentik mengenai perbuatan, perjanjian dan ketetapan yang diharuskan oleh perundang-undangan dan/atau yang dikehendaki oleh yang berkepentingan untuk dinyatakan dalam bentuk akta otentuj, menjamin kepastian tanggal pembuatan

7 M. Yahya Harahap. 2013. Hukum Perseroan Terbatas, Jakarta: Sinar Grafika, hlm 376. akta, menyimpan akta, memberikan grosse, salinan dan kutipan akta, semuanya itu sepanjang pembuatan akta-akta itu tidak juga ditugaskan atau dikecualikan kepada pejabat lain atau orang lain yang ditetapkan oleh undangundang.

Melalui pengertian Notaris tersebut terlihat bahwa tugas seorang Notaris adalah menjadi pejabat umum, sedangkan wewenangnya adalah membuat akta otentik. ${ }^{8}$ Sedangkan akta otentik adalah suatu akta yang bentuknya ditentukan oleh undang-undang, dibuat dihadapan pegawai-pegawai umum yang berkuasa untuk itu di tempat di mana akta itu dibuatnya. Akta Notaris sebagai akta otentik dibuat menurut bentuk dan tata cara yang telah ditetapkan oleh undang-undang. ${ }^{9}$

Jika memang Notaris melakukan rangkap jabatan berarti Notaris tersebut secara sadar melakukannya dan secara undang-undangan jabatan Notaris dilanggar, walaupun sudah jelas tertera bahwa Notaris dilarang merangkap jabatan sebagaimana yang termuat dalam Pasal 17 huruf c,d,e,f lik kepentingag. Dan ketika hal ini dilakukan tentu Notaris yang bersangkutan telah melanggar ketentuan undang-undang dan menurut Pasal 85 bahwa jila melanggar ketentuan Pasal 17 maka akan dikenakan saksi berupa teguran lisan, teguran tertulis, pemberhentian sementara, pemberhentian dengan hormat dan pemberhentian dengan tidak hormat.

Banyak hal yang akan terjadi ketika Notaris merangkap jabatan sebagaimana disebut di atas antara lain adalah terjadinya benturan kewenangan antar jabatan. Benturan kewenangan (conflict of interest) adalah suatu situasi di mana terdapat konflik kepentingan,

\footnotetext{
8 Op. Cit, hlm 16

9 Ibid,
} 
kedudukan dan wewenang yang dimilikinya (baik dengan sengaja atau tidak sengaja), sehinga tugas yang dilaksanakan itu tidak akan optimal dijalankan. Apalagi jika benturan kepentingan ini menyangkut hal-hal yang penggunaan jabatan untuk kepentingan pribadi atau golongan. Selain itu akan sangat sulit dalam hal terjadinya pengawasan terhadap rangkap jabatan ini di mana kewenangan yang satu dengan yang lain sangat berbeda, ada juga rangkap jabatan yang yang secara nyata tidak memenuhi criteria tata kelola yang baik dan nyata ini akan menimbulkan benturan kepentingan. Dan rangkap jabatan itu sendiri bisa juga mengakibatkan diambilnya keuntungan dari rangkap jabatan tersebut.

Dan disini jika Notaris merangkap jabatan sebagai direktur maka akan berakibat pada benturan kepentingan dan juga pasti akan terjadi penyalahgunaan wewenang. Bahwa setiap kewenangan itu memiliki tujuan tertentu yakni tujuan diberikan kewenangannya ini yang dalam konsep hukum dikenal dengan ketajaman arah dan tujuan sehingga dalam pelaksanaannya penegakan hukumnya harus selaras dan seimbang dengan tujuan dan kewenangan yang diberikan.

Demikian pula halnya dengan tugas dan kewenangan antara Notaris dan Direksi adalah berbeda. Notaris di dalam Pasal 1 angka 1, Notaris yang didefisinikan sebagai pejabat umum yang berwenang untuk membuat akta otentik dan kewangangan lainnya sebagaimana diatur dalam UUJN. Definisi yang diberikan oleh UUJN ini merujuk pada tuags dan wewenang yang dijalankan oleh Notaris. Artinya Notaris memiliki tugas sebagai pejabat umum dan memiliki wewenang membuat akta otentik serta kewenangan lainnya yang diatur oleh UUJN. ${ }^{10}$

Notaris, adalah profesi yang sangat penting dan dibutuhkan dalam masyarakat, mengingat fungsi dan Notaris adalah pembuat alat bukti tertulis mengenai akta-akta oetentik, sebagaimana yang tercantum dalam Pasal 1868 KUH Perdata. Adapun yang dimaksud dengan akta otentik berdasarkan Pasal 1868 KUH Prerdata adala "Suatu akta otentik adalah suatu akta yang di dalam bentuk yang ditentukan oleh undang-undang dibuat oleh atau dihadapan pegawai-pegawai umum yang berkuasa untuk itu di tempat di mana akta dibuatnya.

\section{PENUTUP}

\section{Kesimpulan}

1. Ratio legis ketentua rangkap Jabatan Notaris sebagaimana tercantum dalam Pasal 17 Undang-Undang Nomor 2 Tahun 2014 tentang Jabatan Notaris adalah mencegah terjadinya Confident of Interst. Dalam hal Notaris merangkap Jabatan sebagai direktur maka sudah bisa jelas dilihat apa adanya perbedaan kewenangan, dan perbedaan kewenangan ini yang ditakutkan terjadinya penyalahgunaan wewenang.

2. Keudukan sebagai direktur sebagaimana ketentuan Pasal 93 ayat (1) UndangUndang Nomor 40 Tahun 2007 Tentang Perseroan Terbatas adalah bahwa yang diangkat untuk menjadi seorang direktur adalah mereka yang cakap melakukan perbuatan hukum dan ada pengecualiannya terhadap pengangkatan seorang sebagai direktur. Tidak ada ha yang mengatur masalah rangkap jabatan seorang direktur.

\section{Saran}

10 Op. Cit, hlm 85. 
1. Seorang Notaris tidak seharusnya melakukan rangkap jabatan karena selain bertentangan dengan ketentuan Pasal 3 dan Pasal 17 Undang-Undang Jabatan Notaris dan Juga diharpkan ada sebuah aturan yang baru yang lebih mempertegas tentang ketentuan rangkap jabatan Notaris karena selain yang termuat di Pasal 17 huruf c, d, e, f, dan g, juga disebutkan jabatan lain yang dilarang untuk dirangkap oleh Notaris.

2. Kedudukan sebagai seorang direktur adalah sebuah tugas yang sangat besar tanggung jawabnya, jadi diharapkan seorang direktur tidak merangkap jabatan dengan pekerjaan lainnya. Demikian pula dengan Notaris, ketika jabatan seorang Notaris dirangkap juga menjadi Direktur ditakutkan akan ada tumpang tindihnya wewenang, sehingga bias menimbulkan penyalahgunaan wewenang.

\section{BIBLIOGRAFI}

Fajar ND, Mukti dan Yulianto Ahmad. 2010. Dualisme Penelitian Hukum Normatif dan Empiris. Yogyakarta : Pustaka Pelajar.

Harahap, M. Yahya. 2013. Hukum Perseroan Terbatas. Jakarta:Sinar Grafika

Mahja, Djuhad. 2005. Undang-Undang Nomor 30 Tahun 2004 tentang Jabatan Notaris. Jakarta : Durat Bahagia.

Marzujuki, Peter Mahmud. 2005. Penelitian Hukum. Jakarta : Kencana.

Susanti, Dyah Ochorina dan A'an Efendi. 2014. Penelitian Hukum (Legal Resarch). Jakarta : Sinar Grafika.

Wordpress.com/2012/11/8/legalitas-rangkapjabatan-organ-PT. diakses 2 Januari 2016.

\section{Peraturan Perundang-Undangan}

Undang - Undang Dasar 1945
Undang-Undang Nomor 40 Tahun 2007 Tentang Perseroan Terbatas. Lembaran Negara Republik Indonesia Tahun 2007 Nomor 106 dan Tambahan Lembaran Negara Republik Indonesia Nomor 4756. Undang-Undang Nomor 2 Tahun 2014 Tentang Perubahan Undang-Undang Nomor 30 Tahun 2004 Tentang Undang-Undang Jabatan Notaris. Lembaran Negara Republik Indonesia Tahun 2014 Nomor 3 dan Tambahan Lembaran Negara Republik Indonesia Nomor 5491 